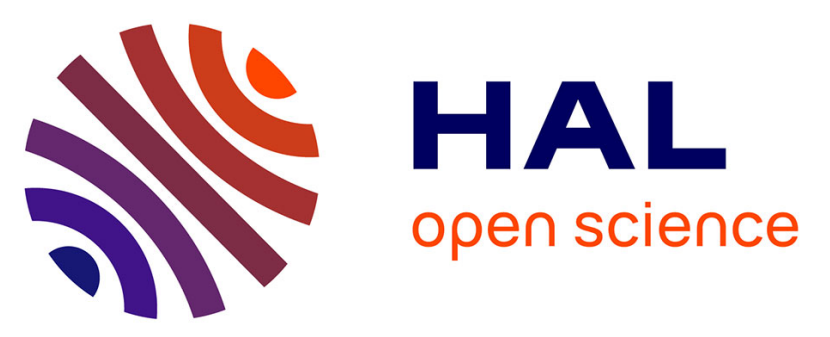

\title{
Satellite telemetry of humpback whales off Madagascar reveals insights on breeding behavior and long-range movements within the southwest Indian Ocean
}

\author{
Salvatore Cerchio, Laurène Trudelle, Alexandre N. Zerbini, Jean-Benoit \\ Charrassin, Ygor Geyer, François-Xavier Mayer, Norbert Andrianarivelo, \\ Jean-Luc Jung, Olivier Adam, Howard C. Rosenbaum
}

\section{To cite this version:}

Salvatore Cerchio, Laurène Trudelle, Alexandre N. Zerbini, Jean-Benoit Charrassin, Ygor Geyer, et al.. Satellite telemetry of humpback whales off Madagascar reveals insights on breeding behavior and long-range movements within the southwest Indian Ocean. Marine Ecology Progress Series, 2016, 562, pp.193 - 209. 10.3354/meps11951. hal-01497122

\section{HAL Id: hal-01497122 \\ https://hal.science/hal-01497122}

Submitted on 26 Nov 2021

HAL is a multi-disciplinary open access archive for the deposit and dissemination of scientific research documents, whether they are published or not. The documents may come from teaching and research institutions in France or abroad, or from public or private research centers.
L'archive ouverte pluridisciplinaire HAL, est destinée au dépôt et à la diffusion de documents scientifiques de niveau recherche, publiés ou non, émanant des établissements d'enseignement et de recherche français ou étrangers, des laboratoires publics ou privés. 


\title{
Satellite telemetry of humpback whales off Madagascar reveals insights on breeding behavior and long-range movements within the southwest Indian Ocean
}

\author{
Salvatore Cerchio ${ }^{1,2, *}$, Laurène Trudelle ${ }^{3,4,5}$, Alexandre N. Zerbini $^{6,7,8}$, \\ Jean-Benoit Charrassin ${ }^{4}$, Ygor Geyer ${ }^{8}$, Francois Xavier Mayer ${ }^{9}$, Norbert \\ Andrianarivelo ${ }^{10}$, Jean-Luc Jung ${ }^{11}$, Olivier Adam ${ }^{3,12}$, Howard C. Rosenbaum ${ }^{13}$ \\ ${ }^{1}$ New England Aquarium, 1 Central Wharf, Boston, MA 02110, USA \\ ${ }^{2}$ Woods Hole Oceanographic Institution, 266 Woods Hole Road, Woods Hole, MA 02543, USA \\ ${ }^{3}$ Bioacoustics Team, Institut de NeuroSciences Paris-Saclay (NeuroPSI), CNRS UMR 8195, Université Paris Sud, 91405 Orsay, \\ France \\ ${ }^{4}$ Sorbonne Universités (UPMC, Univ. Paris 06)-CNRS-IRD-MNHN, LOCEAN-IPSL, 4 place Jussieu, 75005 Paris, France \\ ${ }^{5}$ Biotope, Unité Recherche et Développement, 22 Boulevard Maréchal Foch, BP 58, 34140 Meze, France \\ ${ }^{6}$ National Marine Mammal Laboratory, Alaska Fisheries Science Center, National Marine Fisheries Service, NOAA, \\ 7600 Sand Point Way NE, Seattle, WA 98125, USA \\ ${ }^{7}$ Cascadia Research Collective, 218 1/2 4th Ave W, Olympia, WA 98501, USA \\ ${ }^{8}$ Instituto Aqualie, Av. Dr. Paulo Japiassú 714/206, Juiz de Fora, MG 36033-310, Brazil \\ ${ }^{9}$ Cetamada, Port Barachois, Ambodifotatra BP 5, 515 Sainte Marie, Madagascar \\ ${ }^{10}$ Institut Halieutique et des Sciences Marines, Université de Toliara, Toliara, Madagascar \\ ${ }^{11}$ BioGemme Laboratory, Brest, France \\ ${ }^{12}$ Sorbonne Université, UPMC Univ Paris 06, CNRS UMR 7190, Institut Jean Le Rond d'Alembert, 75005 Paris, France \\ ${ }^{13}$ Wildlife Conservation Society, Ocean Giants Program, 2300 Southern Blvd, Bronx, NY 10460, USA
}

\begin{abstract}
Humpback whales breeding in the southwest Indian Ocean are thought to exhibit population substructure between Madagascar and east Africa. To investigate regional movements, breeding behavior and habitat utilization, 23 whales were satellite-tagged off Madagascar during peak breeding season off the northeast and southwest coasts. Mean tag duration was $24.2 \mathrm{~d}$ ( 3 to $58 \mathrm{~d}$ ), during which time no individual remained near the immediate tagging sites and several displayed extensive long-range movements. We applied a switching state-space model to estimate behavioral modes of 'transiting' (b-mode approaching 1.0) vs. 'localized' (b-mode approaching 2.0) movement. A general linear mixed-effects model indicated females were more likely to display transiting behavior than males (mean b-mode females $=1.27$, males $=1.65 ; \mathrm{p}=0.031$ ). Whales tagged in the northeast displayed localized movements off the central east coast of Madagascar, whereas whales tagged in the southwest displayed localized movements on the southern coasts, with little overlap. Long-distance movements included north-westerly trajectories to eastern Africa and southerly transits to Walters Shoals and the Crozet Islands. Despite these long-range movements in short periods, no whale travelled to the northwest coast of Madagascar, nor to Mozambique or the Mascarene Islands. These results suggest there may be more interchange between Madagascar and central-east Africa than previously thought, and whales off east and west Madagascar may not use the same habitat within breeding seasons; important findings for defining sub-population structure and conservation management strategy. Furthermore, male mating strategy may involve more localized searching or displaying, whereas females travel more extensively during the breeding season, observations that are consistent with a large-scale lek mating system.
\end{abstract}

KEY WORDS: Humpback whales $\cdot$ Satellite telemetry $\cdot$ Madagascar $\cdot$ Breeding behavior $\cdot$ Movement patterns $\cdot$ Population structure 


\section{INTRODUCTION}

Humpback whales Megaptera novaeangliae, globally, are seasonal breeders, and with few exceptions, populations migrate yearly between high-latitude feeding regions in summer and low-latitude breeding regions in winter. Migrations are extensive, with latitudinal migratory movements of several thousand kilometers in different ocean basins (Mate et al. 1998, Zerbini et al. 2006, Rasmussen et al. 2007, Lagerquist et al. 2008, Kennedy et al. 2014, Rosenbaum et al. 2014). The mating system is generally agreed to be polygynous, with elements of lekking and male dominance polygyny (Herman \& Tavolga 1980, Clapham 1996, 2000, Cerchio et al. 2005). Females reproduce on average once every 2 to $3 \mathrm{yr}$ and likely have a short estrus period (Chittleborough 1958, 1965, Clapham \& Mayo 1990), resulting in a severely skewed operational sex ratio (Clapham 2000). Gestation lasts $1 \mathrm{yr}$, with both conception and parturition generally occurring during a 5 mo period centered in winter. Thus, in a breeding region, females can be subdivided into 2 reproductive classes: adult females without calves and with relatively high fecundity (termed 'non-parous females' throughout) that have migrated solely to become fertilized; and postpartum females with a calf-of-the-year (termed 'mothers' throughout) that have relatively low fecundity since only a small fraction of females give birth in consecutive years (Clapham \& Mayo 1990, Clapham 1996). Males exhibit alternative mating tactics while on the breeding grounds, including a male-limited acoustic display or song (Payne \& McVay 1971), intense physical competition among groups of males for single estrous females in 'competitive groups' (Tyack \& Whitehead 1983), and 'escorting' of mothers with a calf-of-the-year (despite their relatively low fecundity). Molecular paternity analysis has indicated polygyny with a slight but significant skew in reproductive success among males and that success is not strongly skewed towards a single tactic (Cerchio 2003, Cerchio et al. 2005).

The International Whaling Commission (IWC) designates 7 breeding stocks around the Southern Hemisphere, labeled A through G (IWC 1998, 2007). The breeding population wintering in the southwest Indian Ocean (SWIO) is labeled breeding stock C and is sub-divided into 4 designated sub-stocks (Fig. 1): in the eastern African coastal waters of South Africa to Kenya (C1), off the islands of the Mozambique Channel (C2), in the coastal waters of Madagascar (C3) and off the Mascarene Islands (C4) (IWC 2007). Modern whaling of humpback whales in the

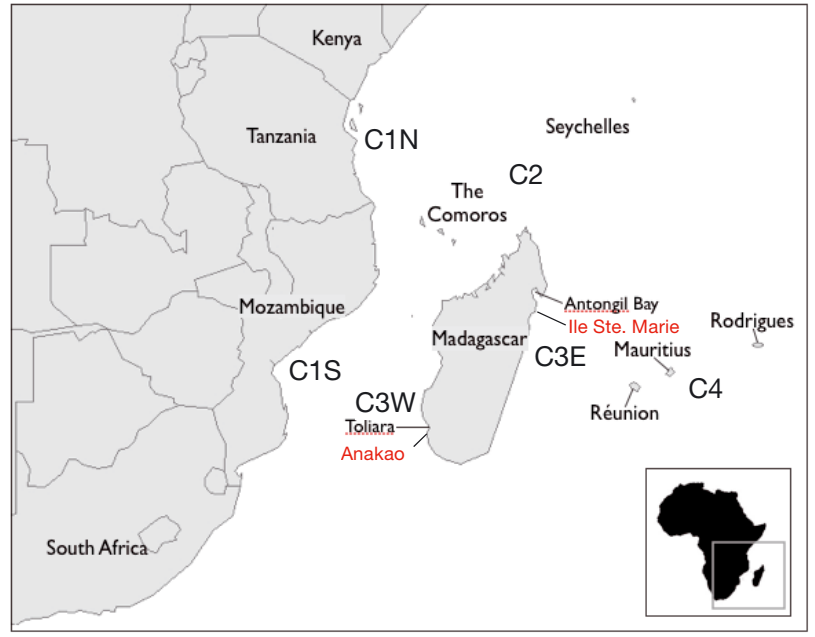

Fig. 1. Southwest Indian Ocean, indicating the key substocks in humpback whale Breeding Stock C. C1: East Africa Mainland (divided into C1S: southern end of range and C1N: northern end of range), C2: Comoros and Seychelles Islands, C3: Madagascar (divided into C3W: western coast and C3E: eastern coast), and C4: Mascarene Islands. Ile Sainte Marie and Anakao are indicated in red, from which satellite tagging of humpback whales was conducted

SWIO began in 1908 and expanded rapidly thereafter, depleting the population, with an estimated 19000 whales taken up until 1963 (Findlay 2001). The first evidence of population structure in the region came from different whaling catch histories in C1 (South Africa/Mozambique, where there was early depletion prior to 1915) as compared to C3 (Madagascar, where catches remained relatively high after 1915), suggesting 2 distinct stocks that were differentially impacted by whaling pressure (Best 1994, Findlay 2001).

In the C1 sub-region, humpback whales migrate past eastern South Africa to a wintering ground off Mozambique, with apparent lower concentrations off Tanzania and Kenya (Findlay et al. 2011a,b, Amir et al. 2012). The relationship between whales in the southern range (Mozambique, C1S) and northern range (Tanzania, Kenya, $\mathrm{C} 1 \mathrm{~N}$ ) is uncertain. In the $\mathrm{C} 2$ sub-region, humpback whales occur around the Comoros Islands and in lesser concentrations around the Seychelles Islands from Aldabra to the Mahe plateau (Kiszka et al. 2010, Ersts et al. 2011a). In the C3 subregion, humpback whales are distributed around the entire island of Madagascar, with most information coming from the northeast (termed here C3E; Fig. 1) in Antongil Bay along with the nearby Ile Sainte (Ste.) Marie (Rosenbaum et al. 1997, Ersts \& Rosenbaum 2003, Pomilla \& Rosenbaum 2006, Cerchio et al. 2009, Vely et al. 2009). A low recapture rate between years 
in Antongil Bay indicated a large population, but recaptured individuals displayed highly regular migratory timing sighted at the same time each year; in addition, recaptures within a season were few and of short duration, suggesting short residency and continuous movement through the area (Cerchio et al. 2009). Concentrations of whales are also known in the southeast and along the west coast, best documented in the southwest (termed here C3W; Fig. 1) around Toliara, where encounter rates are similar to Antongil Bay (S. Cerchio pers. obs.). The relationship of animals utilizing the east coast (C3E) and west coast (C3W) of Madagascar is unknown, so it is not clear whether they represent the same or distinct substocks. In the C4 sub-region, humpback whales are distributed around the islands of Réunion, Mauritius and Rodrigues, but appear to be relatively recent arrivals since approximately 2008, suggesting a range expansion from other areas in the SWIO (DulauDrouot et al. 2012). Within-year recapture rate off Réunion is relatively high, with long apparent residency times for at least a subgroup of individuals; however, whales sighted early in the season appear more transient (Dulau-Drouot et al. 2011, 2012).

There is significant genetic differentiation between $\mathrm{C} 1$ and $\mathrm{C} 3$ animals at both mitochondrial and nuclear microsatellite loci; however, differentiation is less pronounced than between the SWIO and adjacent stocks in the southeast Atlantic and southeast Indian Oceans (Rosenbaum et al. 2009, Kershaw et al. 2016). Converse to the $\mathrm{C} 1-\mathrm{C} 3$ relationship, there is no significant differentiation between C2 and C3 (Rosenbaum et al. 2009, Kershaw et al. 2016). Similarly, capture-recapture studies indicate low probability of exchange of individuals between C1 and C3 (Cerchio et al. 2008) and apparently greater exchange between $\mathrm{C} 2$ and $\mathrm{C} 3$ (Ersts et al. 2011b) and between C3 and C4 (DulauDrouot et al. 2011). Despite significant population structure and low probability of interchange based on capture-recapture analyses, estimated long-term gene flow rates and effective migrants per generation between sub-stocks $\mathrm{C} 1$ and $\mathrm{C} 3$ were relatively high in comparison to different adjacent stocks (Rosenbaum et al. 2009, Kershaw et al. 2016).

Thus, current information suggests that humpback whales are heterogeneously distributed throughout the SWIO, and there is distinct population structure between at least sub-populations in the $\mathrm{C} 1$ and $\mathrm{C} 3$ sub-regions. The sub-population identity of $\mathrm{C} 2$ and $\mathrm{C} 4$ is less clear; however, it is possible that each may have greater interaction with $\mathrm{C} 3$ and perhaps represent range expansions from C3. Alternatively, due to its proximity in the Mozambique Channel, C2 may have more interaction with $\mathrm{C} 1$ than currently documented and may act as a conduit for exchange of animals (and genes) between C1 and C3. Migratory corridors, specific routes of travel, and the degree of route fidelity among animals from the same or different sub-region, are completely unknown. These unknowns carry consequence for our understanding of population status (i.e. abundance and growth rate), delineation of sensitive habitat, and management and protection of the population.

The purpose of this study was to use satellite telemetry to describe movements of individuals during the breeding season and thereby make inferences on the breeding behavior, preferred breeding habitat and sub-population connectivity of humpback whales in the southwestern Indian Ocean. These factors were assessed by tracking the movements of individual, satellite-tagged whales on both the east and west coast of Madagascar which represent the C3 designated breeding sub-stock. Implantable satellite tags have been used to remotely monitor movements of various large whale species, including humpback whales (Zerbini et al. 2006, 2011, Dalla Rosa et al. 2008, Garrigue et al. 2010, Hauser et al. 2010). Satellite telemetry is ideal for providing information on the behavior of individuals and improving the understanding of a population substructure which has been previously inferred through genetic and recapture studies, as well as for addressing previously unexplored questions such as those regarding behavioral differences between sexes and wide-scale habitat utilization during the breeding season. By tagging whales off both the east and west coasts of Madagascar during the peak breeding season, we assessed the relationship between animals in the sub-regions $\mathrm{C} 3 \mathrm{E}$ and $\mathrm{C} 3 \mathrm{~W}$ and their interactions with the other sub-stocks, i.e. C1, C2 and C4.

\section{MATERIALS AND METHODS}

\section{Tag technology and deployment}

The tags used were Wildlife Computers (Redmond, WA, USA) SPOT 5 transmitters within implantable cylinder housings (Wildlife Computers Mold 193) and anchoring systems were a modified version of the Gales et al. (2009) design. The tags are designed to penetrate to a maximum of $290 \mathrm{~mm}$ into the dorsal surface of the whale, generally just forward and to the side of the dorsal fin, and to anchor within the variable muscle and connective tissue matrix (the fascia) that underlies the blubber. Tag retention is maintained by 
passively deployed sets of barbs. All external components of the tag are built from surgical-quality stainless steel. Tag deployment was carried out from the bow of a small boat at distances of 3 to $5 \mathrm{~m}$ using a tagging pole (Heide-Jørgensen et al. 2003, Zerbini et al. 2006) or a modified pneumatic tagging device (HeideJørgensen et al. 2001, Gales et al. 2009).

\section{Sampling design}

Of priority interest were movements of whales during the breeding season and resultant implications for stock structure and breeding behavior, with lower priority given to migration routes to summer feeding destinations. For this reason, we tagged during the period of peak whale density in the breeding season, as opposed to late season which would maximize potential for migratory movements and increased tag duration but miss within-region movements. Tagging was conducted off the northeast coast of Madagascar from Ile Sainte Marie in 2012 and off the southwest coast from the village of Anakao in 2013 (see Fig. 1). These regions were known to have high densities of humpback whales during the breeding season.

An attempt was made to tag equal proportions of adult females and males in order to evaluate differences between the sexes. Both mothers and nonparous females were targeted in equal proportions since reproductive status may affect intra-regional movements and timing of migration. Males and females are impossible to morphologically distinguish from a boat, presenting a challenge for this targeted sample design. Mothers are readily distinguished from males because they are accompanied by a small calf in close association. A non-parous female can be distinguished based upon behavioral cues when the female is the focus of competition between males in a 'competitive group' (Tyack \& Whitehead 1983, Clapham et al. 1992). In a typical competitive group, a female, termed the 'nuclear animal' (NA), is closely guarded by an adult male, termed the 'principal escort' (PE), while a number of additional males, termed 'secondary escorts' (SE), follow the pair; some SEs attempt to supplant the PE and are designated 'challengers' $(\mathrm{CH})$. With adequate observation of position and behaviors, the different roles can be diagnosed allowing inference about sex for both non-parous females (NAs) and adult males (PEs, SEs and CHs). In addition to these behavioral categories, whales were tagged as escorts accompanying mothers (esc), as members of a pair of whales (pair) and when found as a solitary individual (solo). Because competition among males can be intense and very physical, it was recognized that tags placed on competitive males could be damaged, shortening the tag duration. We further attempted to tag males and females in associated pairs, either as the 'NA' and ' $\mathrm{PE}^{\prime}$ ' in a competitive group, or as a mother and her escort in a mother/calf/escort trio. Tagged whales were biopsied using standard biopsy equipment (crossbow with biopsy dart) and photographed for individual identification using tail flukes (when possible) and dorsal fins. Whole genomic DNA was extracted from biopsy skin tissue samples using the DNeasy Blood and Tissue Kit (Qiagen) and the sex of whales was confirmed using simultaneous PCR amplification of $S R Y$ and $Z F X / Z F Y$ gene fragments (Jayasankar et al. 2008).

\section{Data collection and analysis}

Tags were duty-cycled in 2012 to be on $6 \mathrm{~h}$ during day (07:00 $\mathrm{h}$ to $13: 00 \mathrm{~h}$ local) and $6 \mathrm{~h}$ at night $(19: 00 \mathrm{~h}$ to $01: 00 \mathrm{~h} \mathrm{local}$ ) and then increased in 2013 to be on $9 \mathrm{~h}$ during day (05:00 $\mathrm{h}$ to $14: 00 \mathrm{~h}$ local) and $9 \mathrm{~h}$ at night (17:00 $\mathrm{h}$ to $02: 00 \mathrm{~h}$ local). Location data were obtained from Service ARGOS by instruments on satellites from the NOAA and the European Organization for the Exploration of Meteorological Satellites (ARGOS User Manual, @ 2007-2016 CLS, www.argossystem.org/manual/). Raw data included a location class defined by increasing number of messages and decreasing uncertainty from $Z, B, A, 0,1,2$ to 3 and an estimate of spatial elliptical error. Prior to analysis, we removed all locations with class of $\mathrm{Z}$ (the least accurate) and applied a speed filter that removed all locations that resulted in a leg speed $>12 \mathrm{~km} \mathrm{~h}^{-1}$ (Garrigue et al. 2010), in order to remove the most likely unrealistic positions.

We fitted a behavioral switching state-space model (SSSM; Jonsen et al. 2003, 2005, 2007, Breed et al. 2009) that estimates model parameters by Markov chain Monte Carlo (MCMC) to the locations of each tagged whale using software R v.2.11.1 (R Core Team 2015) and WinBUGS v.1.4 (Bayesian inference Using Gibbs Sampling Project). SSSMs simultaneously solve a model of observation error and a mechanistic model of animal movement (Jonsen et al. 2005) and yield better estimates of the locations and the uncertainty in those locations than raw tracking data. This is because the SSSM draws on all of the data and the animal's behavior (e.g. speed and turning angles) to predict the probability of an animal being found at a certain location (Jonsen et al. 2003, 2005). To make data comparable between the 2 years and to combine 
years for a comparison of sexes, 2013 data were subsampled to match the $6 \mathrm{~h}$ on:6 $\mathrm{h}$ off duty cycle of 2012 data prior to running the SSSM. We estimated locations and associated credibility intervals twice daily, once during the day and once at night, equivalent to a $12 \mathrm{~h}$ time step. Behavioral state was classified on the basis of 2 parameters: mean turning angle $(\theta)$ and autocorrelation in speed and direction $(\gamma)$. We ran 2 MCMC chains in parallel, each for 50000 iterations, including a burn-in of 20000 iterations which were discarded. The remaining samples were further thinned by retaining every $30^{\text {th }}$ sample to reduce autocorrelation; the retained iterations were used to estimate the mean and variance for each location and its respective behavioral state. Thus, the posterior distribution for each parameter was based on 1000 samples from each chain, giving a total of 2000 independent samples. The 2 behavioral states were differentiated by a separation of the values of the 2 parameters $(\theta$ and $\gamma)$, resulting in 'b-mode' state values of 1 or 2 for each iteration and a mean b-mode calculated for each estimated position across all iterations. We nominally referred to the 2 states as: 'transiting', which were highly directional (turning angles near $0^{\circ}$ ) and consistent long-distance movements, likely representing transits through breeding habitat or between distinct breeding habitats (b-mode state of 1); and 'localized', which were more variable movements with a higher rate of acute turning angles (near $180^{\circ}$ ), likely representing searching behavior or meandering within breeding habitats (b-mode state of 2). Spatial distribution of behavioral states were evaluated by plotting the standardized mean of b-modes on a $0.3^{\circ}$ grid, so that each grid cell contained a mean of individual means for all positions in that cell.

Linear mixed-effects models (Pinheiro \& Bates 2000, Zuur et al. 2009) were used to evaluate the influence of diel period (day and night), Julian day, moon phase, tagging day, sex and tagging site on the SSSM-estimated behavioral mode using the package nlme (Pinheiro et al. 2015) with R v.3.2.0 (R Core Team 2015). The response variable (behavioral mode) was logit transformed prior to analysis, 'tagged individuals' were used as a random effect and an $\operatorname{ARMA}(2,0)$ autocorrelation structure was used to account for lack of temporal independence within telemetry data for each whale. Choice of the best correlation structure and model selection followed the procedures outlined by Zuur et al. (2009): nested models were fit using maximum likelihood, candidate models were ranked using the Akaike information criterion (AIC), and the most supported model was then fitted using restricted maximum likelihood.

\section{RESULTS}

\section{Tag results summary}

Twelve humpback whales were satellite-tagged off Ile Ste. Marie, Madagascar, between 24 July and 3 August 2012 and 11 whales were tagged off Anakao, Madagascar, between 16 and 28 July 2013 (Table 1). We succeeded in tagging a cross-section of sexes, reproductive classes and behavioral subclasses, with relatively equal representation of sexes despite the relatively small sample size (see Table 1 for details on sex and subclass composition). Tagged whales consisted of 7 males and 5 females off Ile Ste. Marie and 3 males and 7 females off Anakao, confirmed by molecular sexing, and 1 of unknown sex off Anakao for which a biopsy was not obtained. Among tagged females, 5 were mothers and 7 were non-parous females.

Mean tag transmission duration was (mean \pm SD) $24.2 \pm 16.1 \mathrm{~d}$ (range 2 to 58 ) for all whales, sexes combined, and $30.1 \pm 18.1 \mathrm{~d}$ (range 2 to 58 ) for females and $17.9 \pm 11.6 \mathrm{~d}$ (range 3 to 34 ) for males. In 2 cases, the tag temporarily stopped transmitting for an extended period, resulting in a gap of $16 \mathrm{~d}$ during the $32 \mathrm{~d}$ duration for Tag 1 (a solo male) and a gap of $12 \mathrm{~d}$ during the $25 \mathrm{~d}$ duration for Tag 4 (a mother). To estimate total track distance for these tags, the shortest navigable distance was measured between the locations on either side of the transmission gap (and added to distances of track segments for total distances, Table 1); for state-space modeling of these individuals, only the temporally longer segment for each tag was modeled. The total number of raw locations per tag ranged from 8 to 807 , and speed filtering reduced raw locations by 5 to $31 \%$ of the original total (Table 1). Filtered track lengths ranged from $73 \mathrm{~km}$ for the shortest duration tag (Tag 16, female, in pair, $2 \mathrm{~d}$ ) to $5631 \mathrm{~km}$ for the longest duration tag (Tag 9, female, NA, $58 \mathrm{~d}$ ).

\section{Description of movements}

Locations and tracks of tagged individuals are grouped by region and sex in Fig. 2 and shown separately for each individual in Fig. $\mathrm{S} 1$ in the Supplement at www.int-res.com/articles/suppl/m562 p193_supp.pdf, using the speed-filtered location data. In some cases, a location occurred on land when an animal was traveling close to the coast due to associated error, and we chose not to delete these locations because they still provide information on 
Table 1. Summary data from 23 humpback whales satellite tagged off Madagascar, at sites in the northeast, Ile St. Marie (SM), and southwest, Anakao (AO). Subclass: Single individual (solo), 1 of 2 individuals in a pair (pair), competitive group (CG), principal escort in a CG (PE), secondary escort in a CG (SE), challenger in a CG $(\mathrm{CH})$, nuclear animal in a CG (NA), mother with calf-of-the-year (mother), escort to a mother (esc). SSSM: switching state-space model, sth migr: southward migration, n/a: not available

\begin{tabular}{|c|c|c|c|c|c|c|c|c|c|c|c|c|}
\hline Tag & Site & Subclass & Sex & Tag date & $\begin{array}{l}\text { Days } \\
\text { trans- } \\
\text { mitting }\end{array}$ & $\begin{array}{c}\text { No. of } \\
\text { raw } \\
\text { locations }\end{array}$ & $\begin{array}{c}\text { No. of } \\
\text { filtered } \\
\text { locations }\end{array}$ & $\begin{array}{c}\text { No. of } \\
\text { SSSM } \\
\text { estimated } \\
\text { locations }\end{array}$ & $\begin{array}{c}\text { Filtered } \\
\text { track } \\
\text { distance } \\
(\mathrm{km})\end{array}$ & $\begin{array}{l}\text { Filtered } \\
\text { mean } \\
\text { speed } \\
\left(\mathrm{km} \mathrm{h}^{-1}\right)\end{array}$ & $\begin{array}{c}\text { Mean } \\
\text { b-mode w/ } \\
\text { sth migr }\end{array}$ & $\begin{array}{c}\text { Mean } \\
\text { b-Mode w/o } \\
\text { sth migr }\end{array}$ \\
\hline 1 & SM & Solo & M & 24-Jul-2012 & 32 & 123 & 101 & 31 & 3250 & 4.3 & 1.30 & \\
\hline 2 & SM & CG & M & 30-Jul-2012 & 31 & 231 & 198 & 61 & 1947 & 1.9 & 1.90 & \\
\hline 3 & SM & Pair & $\mathrm{M}$ & 30-Jul-2012 & 20 & 169 & 143 & 38 & 1551 & 2.2 & 1.73 & \\
\hline 4 & $\mathrm{SM}$ & Mother & $\mathrm{F}$ & 31-Jul-2012 & 25 & 58 & 51 & 25 & 2261 & 1.8 & 1.52 & \\
\hline 5 & SM & Esc & $\mathrm{M}$ & 31-Jul-2012 & 5 & 21 & 15 & $\mathrm{n} / \mathrm{a}$ & 489 & 1.7 & $\mathrm{n} / \mathrm{a}$ & \\
\hline 6 & SM & Pair & M & 31-Jul-2012 & 10 & 71 & 60 & 19 & 689 & 1.7 & 1.80 & \\
\hline 7 & SM & Mother & $\mathrm{F}$ & 31-Jul-2012 & 13 & 102 & 88 & 26 & 1187 & 2.1 & 1.05 & \\
\hline 8 & SM & $\mathrm{CH} / \mathrm{PE}$ & M & 1-Aug-2012 & 3 & 21 & 17 & $\mathrm{n} / \mathrm{a}$ & 112 & 1.3 & $\mathrm{n} / \mathrm{a}$ & \\
\hline 9 & SM & NA & $\mathrm{F}$ & 1-Aug-2012 & 58 & 368 & 300 & 115 & 5631 & 3.3 & 1.21 & 1.24 \\
\hline 10 & SM & Mother & $\mathrm{F}$ & 1-Aug-2012 & 30 & 222 & 200 & 60 & 2444 & 2.5 & 1.32 & \\
\hline 11 & SM & $\mathrm{PE}$ & M & 3-Aug-2012 & 15 & 104 & 82 & 29 & 1018 & 1.7 & 1.66 & \\
\hline 12 & SM & NA & $\mathrm{F}$ & 3-Aug-2012 & 23 & 196 & 174 & 45 & 2549 & 3.8 & 1.04 & \\
\hline 13 & $\mathrm{AO}$ & Pair & $\mathrm{U}$ & 16-Jul-2013 & 15 & 206 & 183 & 31 & 1388 & 4.1 & 1.32 & \\
\hline 14 & $\mathrm{AO}$ & Pair & $\mathrm{F}$ & 17-Jul-2013 & 21 & 8 & 6 & $\mathrm{n} / \mathrm{a}$ & 759 & 1.6 & $\mathrm{n} / \mathrm{a}$ & \\
\hline 15 & $\mathrm{AO}$ & Pair & $\mathrm{F}$ & 17-Jul-2013 & 42 & 473 & 432 & 84 & 3729 & 4.2 & 1.22 & \\
\hline 16 & $\mathrm{AO}$ & Pair & $\mathrm{F}$ & 17-Jul-2013 & 2 & 13 & 9 & $\mathrm{n} / \mathrm{a}$ & 73 & 3.8 & $\mathrm{n} / \mathrm{a}$ & \\
\hline 17 & $\mathrm{AO}$ & Pair & M & 17-Jul-2013 & 34 & 480 & 444 & 67 & 2639 & 3.8 & 1.50 & \\
\hline 18 & $\mathrm{AO}$ & $\mathrm{PE}$ & $\mathrm{M}$ & 21-Jul-2013 & 23 & 307 & 280 & 44 & 1652 & 3.6 & 1.73 & \\
\hline 19 & $\mathrm{AO}$ & SE & M & 21-Jul-2013 & 8 & 85 & 81 & 10 & 737 & 4.6 & 1.58 & \\
\hline 20 & $\mathrm{AO}$ & Mother & $\mathrm{F}$ & 23-Jul-2013 & 23 & 269 & 247 & 35 & 1766 & 4.0 & 1.08 & \\
\hline 21 & $\mathrm{AO}$ & NA & $\mathrm{F}$ & 25-Jul-2013 & 17 & 129 & 116 & 33 & 1221 & 4.1 & 1.53 & \\
\hline 22 & $\mathrm{AO}$ & NA? & $\mathrm{F}$ & 27-Jul-2013 & 56 & 786 & 696 & 104 & 4341 & 3.7 & 1.37 & 1.65 \\
\hline 23 & $\mathrm{AO}$ & Mother & $\mathrm{F}$ & 28-Jul-2013 & 52 & 807 & 765 & 103 & 3191 & 3.3 & 1.37 & \\
\hline
\end{tabular}

the complete track of the individual. No individuals remained in the immediate vicinity (within $50 \mathrm{~km}$ ) of the tagging sites for $>3 \mathrm{~d}$ and most moved out of the area within $1 \mathrm{~d}$. Observed movements were categorized into 4 subclasses: (1) movement along the central east coast of Madagascar, primarily from Ile Ste. Marie, (2) movement along the south and southeast coast of Madagascar, primarily from Anakao, (3) northbound movements and departure from Madagascar, only from Ile Ste. Marie, and (4) southbound movements and departure from Madagascar, from both Ile Ste. Marie and Anakao. Descriptions of movements in each category are as follows (with tag numbers corresponding to those listed in Table 1 and depicted in Fig. S1).

\section{Central east coast movements}

Five males (Tags 2, 3, 6, 8 and 11) tagged off Ile Ste. Marie in 2012 spent the entire duration (ranging from 3 to 29 d between 30 July and 29 August 2012) along an approximately $550 \mathrm{~km}$ stretch of the Madagascar central east coast south of Ile Ste. Marie and north of latitude $22^{\circ} \mathrm{S}$, a region not previously recognized as active breeding habitat (Fig. 2B). Three females (Tags 9, 10 and 12) also spent time in the same general stretch of coast south of Ile Ste. Marie, as part of more extensive travel during relatively similar amounts of time as the 5 males (Fig. 2A,B), including departure from Madagascar to the south and north (Tags 9 and 12, respectively), described below. One mother (Tag 10) traveled steadily north from 1 to 8 August 2012 approximately $640 \mathrm{~km}$ to the north tip of Madagascar and then traveled back south approximately $1000 \mathrm{~km}$ from 9 to 30 August, with some meandering off the central east coast region. Only 2 individuals tagged off Anakao in 2013 traveled up the east coast of Madagascar into this region, and notably they were the only mothers tagged off Anakao (Tags 20 and 23), such that no male or nonparous female displayed these movements (Fig. 2C). One of the mothers (Tag 23) reversed direction about $140 \mathrm{~km}$ south of Ile Ste. Marie and traveled back to the southeast corner of Madagascar before the tag ceased transmitting. 

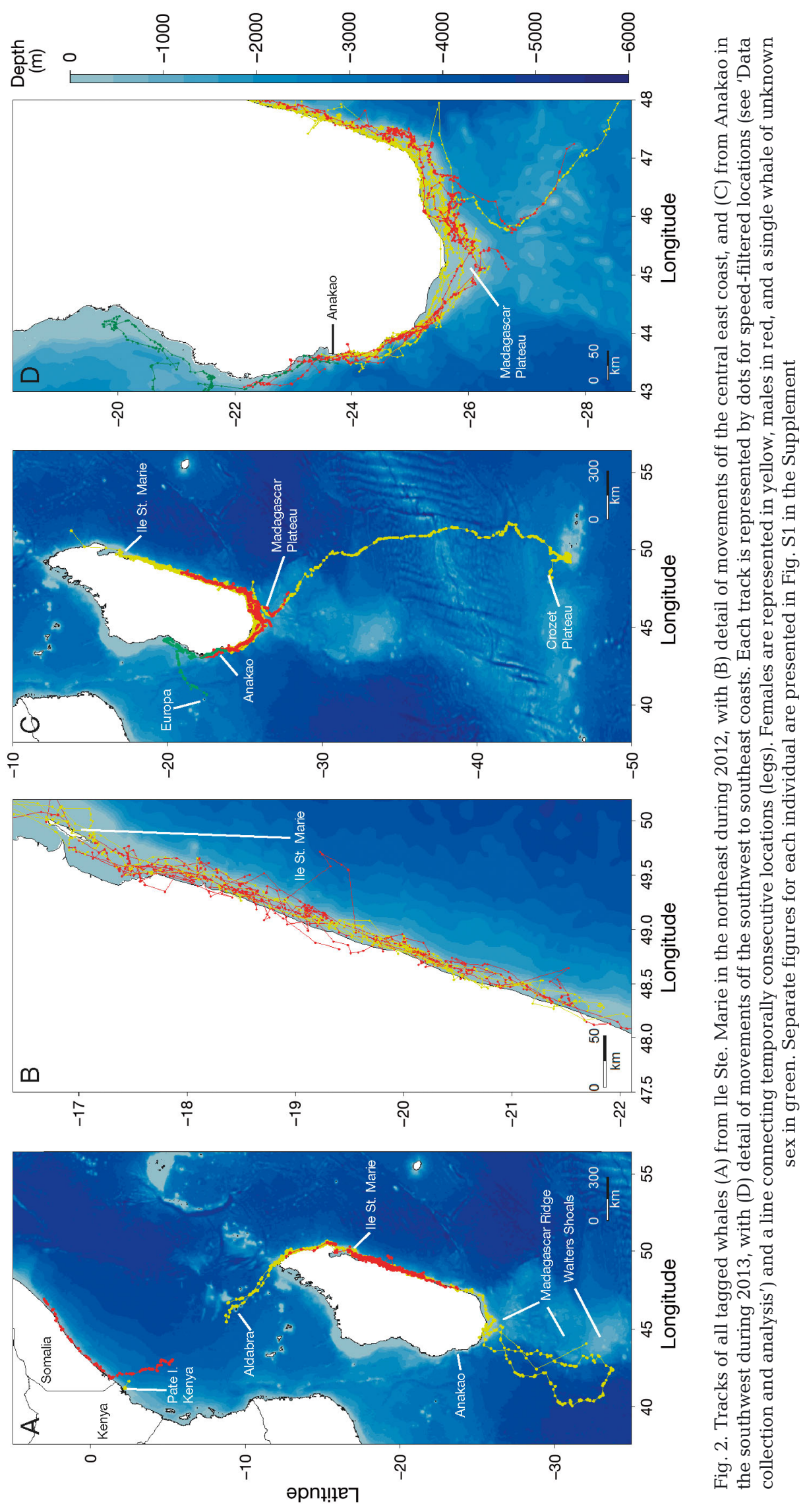


\section{South and southeast coast movements}

Only 1 whale tagged off Ile Ste. Marie in 2012 visited the south or southeast of Madagascar, a female tagged as an NA (Tag 9) that moved directly to the south and lingered for $6 \mathrm{~d}$ on the Madagascar Plateau before more extensive southerly movements described below (Fig. 2A). Conversely, all but 1 individual tagged off Anakao in 2013 that transmitted for more than a few days travelled to the south and southeast coast of Madagascar (Fig. 2C,D; Tags 14, 15 and 17-23). A non-parous female tagged in a pair (Tag 15) traveled approximately $1000 \mathrm{~km}$ around the south of Madagascar and up the east coast to latitude ca. $21^{\circ} \mathrm{S}$ between 17 July and 1 August 2013, reversed the route back to Anakao and then repeated the same general path before the tag stopped transmitting while on the Madagascar Plateau on 28 August 2013. A male tagged in a pair (Tag 17) followed a similar pattern, travelling to approximately the same point up the southeast coast by 5 August 2013, before turning back south and eventually departing Madagascar on 16 August 2013. Two males (Tags 18 and 19) and 2 non-parous females (Tags 21 and 22) also traveled to the south coast and meandered on the Madagascar Plateau to varying degrees between 21 July and 15 August 2013.

\section{Northbound movements}

Five animals, 2 males and 3 females, traveled north from Ile Ste. Marie, 4 of which departed Madagascar on similar northwesterly trajectories (Fig. 2A). Two females (a mother, Tag 7, and a non-parous NA, Tag 12) travelled north ultimately to a location beyond Aldabra Atoll when the tags stopped transmitting, traveling approximately $450 \mathrm{~km}$ in $4 \mathrm{~d}$ and $500 \mathrm{~km}$ in $3 \mathrm{~d}$ after departing Madagascar on 8 August 2013 and 21 August 2012, respectively. The NA (Tag 12) appeared to linger around Aldabra for $1 \mathrm{~d}_{i}$ however, both females passed through the Aldabra region and were still moving to the northwest when the tags stop transmitting. This represents over $1100 \mathrm{~km}$ covered in $13 \mathrm{~d}$ for the Tag 7 mother and over $2300 \mathrm{~km}$ in $23 \mathrm{~d}$ for the Tag 12 female.

Two individuals, a male (solo) and a female (mother), traveled to the central east African coast, but in both cases, the tag did not transmit for the entire transit, so the path can only be inferred (Fig. 2A). The mother (Tag 4) travelled approximately $600 \mathrm{~km}$ north between 31 July and 7 August 2012 to the north tip of Madagascar before the tag temporarily stopped trans- mitting. The tag began to report again on 20 August 2012, when the mother was approximately $15 \mathrm{~km}$ off Pate Island, off the north coast of Kenya. The shortest navigable distance between the 2 end locations is $1497 \mathrm{~km}$, so it is likely that she moved steadily on a direct course during the $12 \mathrm{~d}$ that would have followed the path of the females Tag 7 and 12 past Aldabra. She then remained within $50 \mathrm{~km}$ of Pate Island for $5 \mathrm{~d}$ before transmissions ceased; the total transit covered over $2100 \mathrm{~km}$ in $25 \mathrm{~d}$. The male tagged as a solo (Tag 1) travelled north $110 \mathrm{~km}$ to the mouth of Antongil Bay before the tag temporarily stopped transmitting on 26 July 2012. The tag began to report again on 12 August 2012, when the male was approximately $390 \mathrm{~km}$ off the coast of Kenya at latitude $5^{\circ} 18.9^{\prime} \mathrm{S}$. The shortest navigable distance between the 2 end locations is $1540 \mathrm{~km}$, so it is likely that he moved steadily on a direct course during the $17 \mathrm{~d}$, again following the same path of the 3 females past Aldabra. This male then covered $450 \mathrm{~km}$ to join the African coast in south Somalia at $1^{\circ} 25.9^{\prime} \mathrm{S}$ on 19 August 2012. Thereafter, he moved steadily north up the Somalia coast for $750 \mathrm{~km}$ in $5 \mathrm{~d}$, crossing the equator before the tag stop transmitting at $2^{\circ} 59.9^{\prime} \mathrm{N}$. During $32 \mathrm{~d}$, he covered over $2800 \mathrm{~km}$ (over $3120 \mathrm{~km}$ of trackline), ending within $1200 \mathrm{~km}$ of the Gulf of Aden.

\section{Southbound movement}

A non-parous female tagged off Ile Ste. Marie as an NA (Tag 9) traveled south immediately after tagging, traveling a somewhat meandering course along the coast approximately $1200 \mathrm{~km}$ between 1 and 21 August 2012 to the south tip of Madagascar. This female lingered on the Madagascar Plateau for $6 \mathrm{~d}$ before departing Madagascar on a meandering southwesterly course west of the Madagascar ridge between 28 August and 9 September to the west edge of Walters Shoals approximately $900 \mathrm{~km}$ south of Madagascar (Fig. 2A). She then turned north and returned to Madagascar between 10 and 18 September, following the west edge of the Madagascar ridge, lingered for $3 \mathrm{~d}$ off the southern tip of Madagascar and finally moved south again $700 \mathrm{~km}$ before the tag stopped transmitting on 27 September. In total, she covered over $5600 \mathrm{~km}$ in $58 \mathrm{~d}$.

A non-parous female tagged off Anakao on 27 July, 2013 in a non-competitive group of 3 whales (Tag 22) moved immediately to the south coast of Madagascar where she lingered on the Madagascar Plateau for $19 \mathrm{~d}$ before departing Madagascar to the south on August 15. This female followed a somewhat mean- 
dering path for $24 \mathrm{~d}$ before arriving on the Crozet Island Plateau on 8 September 2013, approximately $2200 \mathrm{~km}$ south of Madagascar (Fig. 2C). The female lingered on the western edge of the plateau approximately $50 \mathrm{~km}$ west of the Crozet Islands before departing in a north-northwesterly direction on 18 September; the tag stopped transmitting 2 d later.

Aside from these 4 general movement categories, 1 whale of unknown sex tagged in Anakao (Tag 13) traveled on a somewhat meandering path $470 \mathrm{~km}$ north of Anakao between 16 and 25 July 2013, before turning back south and departing the coast of Madagascar on a southwesterly course on 27 July (Fig. 2C). The tag stopped transmitting after another $5 \mathrm{~d}$ and $380 \mathrm{~km}$, when the whale was off Europa Island. This was the only case both of a whale moving north up the west coast and departing Madagascar across the Mozambique Channel.

\section{Behavioral observations of tagged male- female pairs}

On 3 occasions, an associated male and female were tagged in the same group, all off Ile Ste. Marie: once as a mother and escort (Tags 4 and 5, respectively), and twice as a PE to an NA in 2 different competitive groups (Tags $8 \& 9$ and Tags $11 \& 12$ ). In the case of the mother and escort, the pair appeared to remain together for the entire period of the time that both tags were transmitting ( $5 \mathrm{~d}$, the period of the shorter duration Tag 5 on the male). In both cases of the PE and NA paired tag events, the 2 whales appeared to remain together for the first $24 \mathrm{~h}$ after tagging, but then diverged on distinctively separate paths thereafter. In addition to these 3 pairs that were tagged within the same group, there were 2 whales tagged separately off Anakao that appeared to join and travel together many days after the tagging event. A male tagged in a pair on 17 July 2013 (Tag 17) and a non-parous female tagged in a noncompetitive group on 27 July 2013 (Tag 22) followed very different paths during the first 30 and $20 \mathrm{~d}$ of the tags' duration, respectively. Then on 16 August 2013, they appear to converge $\sim 40 \mathrm{~km}$ off the edge of the Madagascar Plateau and tightly follow the same positions, course and timing for $3 \mathrm{~d}$ and $285 \mathrm{~km}$ until Tag 17 stopped transmitting on August 19 (Fig. 2C,D; see the 2 tracks departing Madagascar in southeasterly direction). Although it is impossible to be certain if they were associated due to error in tag positions, it appears likely that they were traveling together, given the timing and close proximity of the locations.

\section{SSSM results}

For the behavioral SSSM analysis, tags that provided $<8 \mathrm{~d}$ of data or $<50$ locations (Tags 5, 8, 14 and 16) were not considered, and only the longer segment of those tags that had a large gap in transmission (Tags 1 and 4) was considered. Females displayed a lower mean b-mode value, 1.27 (1.30 when removing southward migration tracks), compared to males, with a mean b-mode of 1.65, suggesting that females engaged primarily in directional transiting movement, whereas males displayed more localized and meandering movement. Average b-modes were similar for animals tagged at either site: 1.45 for Ile Ste. Marie and 1.42 for Anakao (1.46 and 1.46, respectively, when removing southward migration tracks). Spatial plots of the standardized mean bmodes clearly show an overall distinction between sexes when comparing all females (Fig. 3A) with all males (Fig. 3B), with male behavior strongly skewed toward localized movements and female movements strongly skewed toward transiting. Females tended to display areas of more localized movement along the central east coast region and south/southeast coast region (Fig. 3C) where males were also displaying the highest degree of localized movements (Fig. 3D). Thus, although females were transiting through these regions, they tended to linger and meander more than when they moved outside of these regions. The movements of whales that left the coastal shelf of Madagascar mostly conformed to transiting behavior, as might be expected. Exceptions to this include male Tag 1, which displayed a period of localized movement approximately $300 \mathrm{~km}$ off the Tanzanian coast (Fig. 3B), female Tag 9, which displayed localized movement at the most southern extent in the vicinity of Walters Shoals and female Tag 22, which displayed localized movement at the most southern extent on the Crozet Plateau (Fig. 3A).

Before linear mixed-effects models were applied to assess variables influencing behavioral state (diel period, Julian day, moon phase, tagging day, sex and

Table 2. Top 3 linear mixed-effects models selected using AIC for humpback whale behavioral state in the breeding grounds off Madagascar. AIC: Akaike information criterion, TagDay: tagging day, DielPer: diel period

\begin{tabular}{|llll|}
\hline Model & df & AIC & $\Delta$ AIC \\
\hline Sex & 6 & 1981.83 & 0.00 \\
Sex + TagDay & 7 & 1983.47 & 1.64 \\
Sex + DielPer & 7 & 1983.75 & 1.92 \\
\hline
\end{tabular}




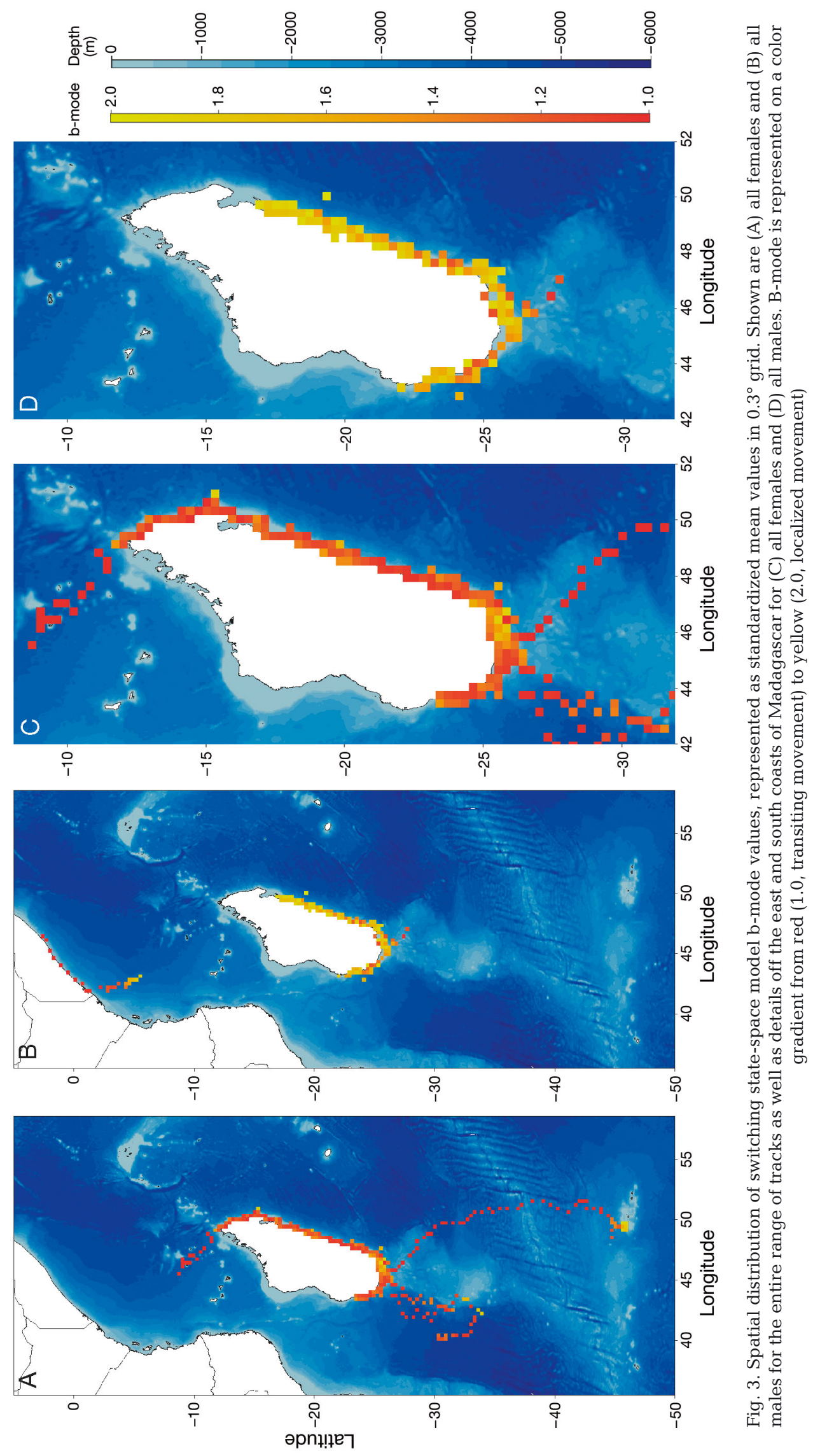


Table 3. Estimates of the fixed-effect coefficient in the most supported mixed-effects model for humpback whale behavioral state in the breeding grounds off Madagascar

\begin{tabular}{|lrrrcc|}
\hline Parameter & Estimate & SE & df & $t$ & $\mathrm{p}$ \\
\hline Intercept & -0.425 & 0.166 & 840 & -2.568 & 0.0104 \\
Sex & 0.612 & 0.260 & 16 & 2.359 & 0.0314 \\
\hline
\end{tabular}

region), portions of tracks for those animals that departed Madagascar from the south were trimmed because these portions were interpreted as southward migratory movements and we sought to assess movements while in the breeding area. The most supported linear mixed-effect model (Table 2) indicated that sex was the only variable to significantly influence the behavioral states of the tagged whales in their breeding grounds off Madagascar. Model coefficients indicated that male b-modes are significantly higher than females (Table 3, Fig. 4), which is consistent with an interpretation that males moved slower and in a more meandering fashion than females during the breeding season.

\section{DISCUSSION}

In this study, we used satellite telemetry in the southwest Indian Ocean to describe movements of humpback whales during the height of the breeding

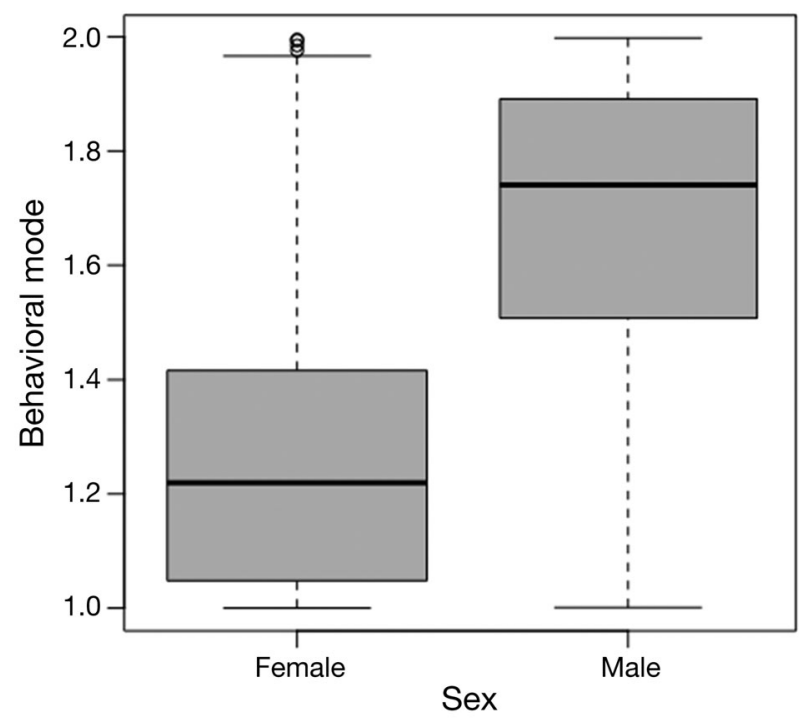

Fig. 4. Boxplot showing distribution of behavioral states of female and male humpback whales in the breeding grounds off Madagascar. Values are the median of the data (central bar), the lower quartiles (box), upper quartiles (whiskers) and outliers (open circles) season, providing some novel inferences on exchange between sub-populations within the region, as well as on breeding behavior and definition of breeding habitat. Despite caveats related to sample size constraints, our individuals displayed a remarkable variety of movement patterns, with consistency among multiple individuals for several different patterns and some unexpected long-range movements in relatively short periods.

\section{Implications for population movements and structure}

Several long-distance movements within the SWIO were documented over relatively short periods of time, all tagged off Ile Ste. Marie. Most notably, 40\% of the 10 whales tagged in Ile Ste. Marie that transmitted $>10 \mathrm{~d}$ displayed long-range movements on the same northwest trajectory towards east Africa. These included a male and a mother that made it to the central east African coast and a non-parous female and a mother that stopped transmitting near Aldabra. These movements to east Africa suggest greater interchange of $\mathrm{C} 1$ and $\mathrm{C} 3$ sub-populations than previously inferred. Studies of genetic differentiation and photographic mark-recapture suggest a population subdivision between whales from $\mathrm{C} 1$ and $\mathrm{C} 3$, although notably with relatively high rates of gene flow compared to that between populations in different ocean basins (Cerchio et al. 2008, Rosenbaum et al. 2009, Kershaw et al. 2016). It is important to note that, in both the genetic and photographic comparisons with $\mathrm{C} 3$, the $\mathrm{C} 1$ samples were collected in the southern portion of the range, in South Africa (a migratory corridor) and southern Mozambique (C1S). The satellite-tagged whales moved directly from Madagascar to the extreme northern portion of the $\mathrm{C} 1$ range, Kenya and Somalia $(\mathrm{C} 1 \mathrm{~N})$. There are currently no genetic or photo-identification data elucidating the relationship between whales that aggregate in the northern and the southern extremes of the $\mathrm{C} 1$ range. Therefore, it is possible that there may be 2 different or partially overlapping migratory streams to the east coast of Africa, one that follows the coastline past South Africa to Mozambique and beyond (as is traditionally described as C1) and a second that passes through the central west Indian Ocean, passing through Madagascar waters en route (as suggested by the individuals tagged in this study). Based on these tagging results, along with population genetic and recapture analyses taken collectively, population substructure and interchange appears to be complex. Recently, the 
IWC completed a comprehensive assessment of this population that estimated post-whaling recovery using models with relatively simple assumptions about population substructure and exchange (Jackson et al. 2015). New inferences implied by these data on exchange between C3 and C1 would likely affect the conclusions of the assessment and further photo-identification, genetic and telemetry studies should be done to elucidate the affiliation of whales off the central East African coast when developing future models.

In addition to the new perspectives that these results imply for sub-stock mixing, novel information was obtained on the specific travel routes through the region. Virtually nothing is known about the direct paths that whales take throughout the west Indian Ocean, beyond the coastal movement along South Africa (Findlay et al. 2011a,b) and scant information from the Mozambique channel based on a few acoustic recordings of song (Best et al. 1998). Here, we have documented a route of travel from Madagascar to Kenya/Somalia through the Outer Seychelles Islands. The large proportion of whales tagged off Ile Ste. Marie that followed this route suggests this may be a prominent movement pattern. Defining important habitat and specific travel routes has particular conservation relevance in relation to threats and habitat degradation associated with the recent discovery of oil and gas reserves and expansion of petroleum industry activities along the east African Coast and in the Mozambique Channel (Rusk \& Bertagne 2014, Tyrrell et al. 2015).

Regarding destinations of these whales, of particular consequence is the movement of a male up the Somali coast, across the equator and into Northern Hemisphere waters to $3^{\circ} \mathrm{N}$ latitude, the first transequatorial movement documented for the Indian Ocean. Aggregations of breeding humpback whales are known from Tanzania and Kenya (Findlay et al. 2011b, Amir et al. 2012), but less is known about regions further north. There are historical and modern observations of whales off the north Somali coast, in the Gulf of Aden and the Red Sea during the Austral winter, and suggestions that they may represent southern hemisphere seasonal migrants or vagrants (Brown 1957, Notarbartolo di Sciara et al. 2014). Trans-equatorial migration of whales from the Southern Hemisphere into breeding areas in low latitudes of the Northern Hemisphere has been documented in the eastern South Atlantic (Rosenbaum et al. 2014) and the eastern South Pacific (Rasmussen et al. 2007). This tagged male had traveled over $2800 \mathrm{~km}$ in $32 \mathrm{~d}$, and when the tag stopped transmitting, the male was within $1200 \mathrm{~km}$ (and $8 \mathrm{~d}$ at last travel rate) of the Gulf of Aden, so it is possible if not likely that it traveled into the Arabian Sea region.

The movement of a SWIO whale into this region has potential implications for our understanding of the north Indian Ocean population of humpback whales in the Arabian Sea. To the best of our knowledge, the Arabian Sea population is isolated from the populations in the Southern Hemisphere, as documented through strong genetic differentiation, lack of any photographic recaptures, small population size, reduced genetic diversity, lack of seasonal migration and a Northern Hemisphere breeding cycle (Rosenbaum et al. 2009, Minton et al. 2010, 2011, Pomilla et al. 2014). Although the Arabian Sea population likely originated from the southern Indian Ocean, it has been isolated for approximately 70000 yr (Pomilla et al. 2014). Given this reported isolation of the Arabian Sea population, and the asynchrony of breeding cycles between Southern and Northern Hemisphere populations, we find it unlikely that this animal's track signifies substantial mixing between SWIO and Arabian Sea animals. However, it does raise questions over potential range overlap, in part due to range expansion by an increasing SWIO population as witnessed in other areas (Dulau-Drouot et al. 2012).

Despite the documented long-range movements within the SWIO in relatively short periods, no whale traveled to the northwestern coast of Madagascar, Mozambique, the Comoros Archipelago or the Mascarene Islands, where breeding aggregations are well-documented. This may simply be a matter of sample size or timing of tagging, and larger samples along with tagging at different times of season may reveal a greater variety of movements and destinations. At least one whale tagged off Anakao started to cross the Mozambique Channel before the tag stopped transmitting, so there is clearly the potential for movement to Mozambique. Fossette et al. (2014) tagged late in the breeding season in the Comoros Archipelago and documented several whales moving to the west and east coast of Madagascar; therefore, there is exchange between these regions at least during southward migration. In a satellite telemetry study off Reunion Island, a majority of whales tagged during peak season moved west to the east coast of Madagascar (V. Dulau pers. comm.). Therefore, there appears extensive exhange between some whales visiting the Mascarene Islands and Madagascar; however, movement may be only or primarily in a westerly direction. 


\section{Southern migration movements}

Although our peak-season timing of tagging deliberately deprioritized detection of late-season migration, we expected to increase the probability of documenting a southward migration in targeting non-parous females. It is logically expected that a female, once impregnated, would return to highlatitude feeding grounds as soon as possible, and non-parous females have been documented with shorter residency times on and earlier departure dates from the breeding grounds (Craig et al. 2003). Two non-parous tagged females displayed what can be considered southward migratory movements. The movement of a female to the Crozet Islands Plateau likely represents a southward migration to feeding habitat, and the localized movement behavior near the Plateau indicated by the SSSM suggests a stop for feeding behavior (see also Trudelle et al. 2016). It is not clear whether this represented a short stop on the way to other feeding grounds, however, because the animal did leave the Crozet Plateau before the tag stopped transmitting. Fossette et al. (2014) also documented a migratory transit to the Crozet Plateau from the Comoros Archipelago, so it appears that this may be a relatively common feeding destination or stopover on the way to other feeding grounds.

The movements of the non-parous female Tag 9 (an NA in a competitive group), which left Madagascar for a long-distance transit to Walter Shoals and then returned $21 \mathrm{~d}$ later, was particularly unexpected. This type of departure and return has not been previously observed in any other humpback whale breeding area from which there are telemetry data, representing a substantial total sample size of tagged whales (Mate et al. 1998, Zerbini et al. 2006, Lagerquist et al. 2008, Horton et al. 2011, Kennedy et al. 2014). Chittleborough (1958) documented through examination of ovaries that females can have multiple ovulations within a season due to failure of fertilization or early failure of pregnancy. This behavior pattern would be an expected prediction of Chittleborough's observation, i.e. if the tagged female was in fact fertilized, but the pregnancy failed, and thus she reentered estrus and returned to again search for mates.

\section{Implications for breeding habitat definition}

The tracks of tagged whales and results of the state-spaced models suggest that the central east coast of Madagascar represents important breeding habitat for humpback whales tagged off Ile Ste.
Marie, whereas the south and southeast coasts represent important breeding habitat for whales tagged off Anakao. Given the distribution of whales around Madagascar, with aggregations in the northeast, southeast and southwest, it was expected that whales would at least transit through the central east coast region; however, our results indicate that whales are utilizing it as preferred breeding habitat. This was not previously recognized, largely due to a lack of research effort in the region and absence of data. The recent development of mining industry activities in Tamatave, located within the stretch of coast utilized by these tagged whales, is of particular conservation consequence due to the potential for coastal pollution from effluents and expanded development.

Existing information for the east coast of Madagascar comes primarily from efforts in Antongil Bay. Concentrations of whales, some with repeated interannual recapture histories, and active breeding habitat have been clearly documented in Antongil Bay (Rosenbaum et al. 1997, Ersts \& Rosenbaum 2003, Pomilla \& Rosenbaum 2006); however, Cerchio et al. (2009) suggested that animals had short residency and were regularly moving through the bay, based on photographic mark-recapture data from 2000 to 2006. This is congruent with our satellite telemetry results indicating that whales move extensively and are utilizing a larger area. Notably, no individuals tagged in Madagascar were documented entering Antongil Bay, despite its close proximity to the tagging location Ile Ste. Marie; similarly, of 7 whales tagged in 2013 off Réunion Island that moved to Madagascar, 5 of them visited the northeast region off Ile Ste. Marie, but none entered Antongil Bay (V. Dulau pers. comm.). Prior to tagging on Ile Ste. Marie, 3 d (21 to 23 July 2012) were spent in Antongil Bay with no sightings of humpback whales, and anecdotal information from whale-watch tourist groups in the bay indicated that 2012 was 1 of $3 \mathrm{yr}$ in the past $10 \mathrm{yr}$ when very few whales were sighted (A. Saloma pers. comm.). On face value, this lack of use of Antongil Bay is unusual given extensive documentation of high densities in the bay during peak season in previous years, 1996 to 2006 (Rosenbaum et al. 1997, Ersts \& Rosenbaum 2003, Cerchio et al. 2008, 2009). Therefore, some variation may exist between years or there may have been a recent shift in distribution patterns, which will require more data and renewed effort in the bay to elucidate.

There was minimal overlap between tracks of individuals tagged off Ile Ste. Marie and Anakao, and a lack of movement to the mid-west and northwest coast of Madagascar, despite such movements representing much shorter transits than the documented 
long-range movements. Whales tagged off Ile Ste. Marie largely favored the central east coast of Madagascar, whereas those tagged off Anakao tended to favor the south and southeast coasts. Those whales that did cross into the other tagging area were females (particularly mothers) that tended to show more transiting movement in general. It appears that whales coming to either side of Madagascar may not use the same breeding habitat within a season or possibly movement patterns may vary substantially at different points in the season and whales may move between east and west Madagascar at other times (i.e. earlier or later in the breeding season, similarly to the movement documented from the Comoros Archipelago to Madagascar at the end of the breeding season; Fossette et al. 2014).

\section{Implications for breeding behavior}

The defined breeding habitat regions were differentially utilized by males and females, with key differences in movement patterns between the sexes in general. Males displayed more variable and localized movement in the defined habitat, whereas females tended to transit through the breeding habitat, covering more distance in shorter periods of time and traveling greater distances overall. However, despite this transiting tendency, females tended toward more localized movement when moving through areas where males were displaying strongly localized movement (the central east coast and the south/ southeast coast regions). This difference between males and females suggests varying mating strategies between the sexes, with males focusing more effort on prospecting a local area for females. Conversely, females may be covering more distance in an effort to expose themselves to a higher number of males, but lingering in areas with higher concentrations of prospecting males. A lek mating system has been suggested for humpback whales (Herman \& Tavolga 1980, Clapham 1996, 2000, Connor et al. 2000), which would entail aggregations of males displaying through song and females moving through aggregations assessing male displays and ultimately exerting female mate choice (Höglund \& Alatalo 1995). The movement patterns described here are consistent with expectations based on the lek hypothesis, particularly when considering an expansive breeding habitat (the central east coast, or the Madagascar Plateau) as large-scale aggregating sites for males through which females move to assess potential mates. Therefore, contrary to classical leks (as in ground birds; Höglund \& Alatalo
1995) where the lekking arena is relatively small, localized and fixed, the lek for humpback whales might be very large, as well as mobile, as suggested by Clapham's (1996) 'floating lek' proposal. It is noteworthy that no clear distinction was apparent between mothers and non-parous females, with examples of both traveling extensive distances in transiting mode. The sample is too small to draw conclusions and further data are required before relevant comparisons can be made between reproductive classes.

Associations among individual humpback whales on the breeding grounds, including between potentially courting males and females, are thought to be transient in nature (Mobley \& Herman 1985, Clapham 1996, 2000). Among 3 male-female pairs tagged in this study, 2 associations appeared to last no more than $1 \mathrm{~d}$; this was not surprising because in both cases the association was between an NA and PE within competitive groups (Tags $8 \& 9$ and $11 \& 12$ ) and thus subjected to disruption by competing males. In the third case, an escort to a mother (Tags 4 and 5), the association appeared to be prolonged for at least $5 \mathrm{~d}$ before the tagged male stopped transmitting. In addition, a male and female not tagged together appeared to join post-tagging and remain together for several days (Tags 17 and 22). Andriolo et al. (2014) found similar periods of association (5 and 4 d) from 2 of 4 pairs tagged off Brazil and also documented pairs apparently coming back together post-tagging. Cerchio (2003), in a molecular paternity assessment off the Revillagigedos Archipelago, Mexico, found 2 cases in which mated male-female pairs were sighted together during the year in which the female was impregnated by that male; each mated pair was seen in association twice over the course of 3 and $9 \mathrm{~d}$, respectively, in 2 CG sightings and 2 pair sightings. Although associations on breeding grounds are clearly fluid, and long-term associations may be rare or absent, it is likely that medium-term associations over at least several days may be important in courtship behavior and reproductive success and may be more common than currently realized.

\section{Future work and perspectives}

This first effort of tracking whales from Madagascar using satellite telemetry has provided new information and some unexpected results. It is clear that there is much more to be learned about this population and region. Tagging during the height of the breeding season provided indications of exchange between breeding areas and definition of preferred 
breeding habitat that would not have been obtained otherwise. The composition of our sample of individuals suggests that it is possible to deliberately target a representative sample across the different sexes and reproductive classes; this is a valuable lesson for future work given the tendency for small sample size in telemetry studies. Future satellite tagging effort should focus on increasing the sample size in each subclass, allowing comparisons across subclasses. Given the documented movement patterns, future tagging off Madagascar should also expand spatial effort, both repeating tagging in the northeast and southwest regions and adding, in particular, the northwest coast of Madagascar, where we documented no movements despite the presence of whales in the late breeding season (Fossette et al. 2014, S. Cerchio pers. obs.). Moreover, these results demonstrate the importance of broad-scale regional collaboration throughout the SWIO and the north Indian Ocean, given the documented extent of whale movements and potential for population mixing and complex substructure. Increasing the available information on movement patterns of humpback whales throughout the Indian Ocean will provide valuable guidance for future research and conservation efforts. The identification of population substructure and connectivity, as well as the preferred habitat throughout the region, are critical for the development of effective conservation management strategies as threats, such as extractive industry and coastal development, increase.

Acknowledgements. Many individuals made this work possible. This study represents a collaborative effort between the Wildlife Conservation Society (WCS, USA), Institute of Neurosciences Paris Saclay (NeuroPSI, France), Association Cetamada (Madagascar) and NOAA National Marine Mammal Lab (NMML, USA). Maria Faria, Henry Bellon, Boris Andrianantenaina and Andrew Wilson provided critical field logistic support and participated in field work; further logistic and administrative support was provided by Sophia Rakotoharimalala, Anjara Salomavola, Sylviane Raharivelo, Luccianie Raonison, Cesaire Ramilison, Rina Ralison, Devon Litherland, Victoria Cordi, Ambroise Brenier and Christopher Holmes. For logistical support in the Anakao region, we thank the staff of IHSM in Toliara, in particular Daniel Ramampiherika and Thierry Lavitra, Thierry Bournonville and the staff of Lalandaka Lodge, Michel Agou and Madame Diamondra from Le Prince Hotel, and the Ministry of Fisheries PACP project. Amy Kennedy provided valuable guidance in analysis. Loriane Mendez, Eric Alfonsi, Eléonore Méheust, Stephen Gaughran and François-Gilles Carpentier provided assistance with molecular analysis. Field work was approved under permit from the Madagascar Ministry of the Environment issued to Cetamada for work around Ile Sainte Marie and to WCS for work around Anakao. Funding for satellite tagging was provided by generous support from the Total Foundation to NeuroPSI and by individuals and foundations to the WCS Ocean Giants Program.

\section{LITERATURE CITED}

Amir OA, Berggren P, Jiddawi NS (2012) Recent records of marine mammals in Tanzanian waters. J Cetacean Res Manag 12:249-253

Andriolo A, Zerbini AN, Moreira S, Pizzorno JL and others (2014) What do humpback whales Megaptera novaeangliae (Cetartiodactyla: Balaenopteridae) pairs do after tagging? Zoologia 31:105-113

Best PB (1994) A review of the catch statistics for modern whaling in southern Africa, 1908-1930. Rep Int Whaling Comm 44:467-485

Best PB, Findlay KP, Sekiguchi K, Peddemors VM, Rakotonirina B, Rossouw A, Gove D (1998) Winter distribution and possible migration routes of humpback whales Megaptera novaeangliae in the southwest Indian Ocean. Mar Ecol Prog Ser 162:287-299

Breed GA, Jonsen ID, Myers RA, Bowen WD, Leonard ML (2009) Sex-specific, seasonal foraging tactics of adult grey seals (Halichoerus grypus) revealed by state-space analysis. Ecology 90:3209-3221

Brown SG (1957) Whales observed in the Indian Ocean: notes on their distribution. Mar Obs 27:157-165

Cerchio S (2003) Paternity, polygyny and alternative mating tactics in humpback whales (Megaptera novaeangliae). $\mathrm{PhD}$ dissertation, University of Michigan, Ann Arbor, MI

* Cerchio S, Jacobsen JK, Cholewiak DM, Falcone EA, Merriwether DA (2005) Paternity in humpback whales (Megaptera novaeangliae): assessing polygyny and skew in male reproductive success. Anim Behav 70:267-277

Cerchio S, Findlay K, Ersts P, Minton G and others (2008) Initial assessment of exchange between breeding stocks $\mathrm{C} 1$ and $\mathrm{C} 3$ of humpback whales in the western Indian Ocean using photographic mark-recapture data, 20002006. Paper SC/60/SH33 presented to the IWC Scientific Committee, May 2008, Cambridge

Cerchio S, Ersts P, Pomilla C, Loo J and others (2009) Updated estimates of abundance for humpback whale breeding stock C3 off Madagascar. Paper SC/61/SH7 presented to the IWC Scientific Committee, May 2009, Cambridge

Chittleborough RG (1958) The breeding cycle of the female humpback whale, Megaptera nodosa (Bonnaterra). Aust J Mar Freshw Res 9:1-18

* Chittleborough RG (1965) Dynamics of two populations of the humpback whale, Megaptera novaeangliae (Borowski). Aust J Mar Freshw Res 16:33-128

Clapham PJ (1996) The social and reproductive biology of humpback whales: an ecological perspective. Mammal Rev 26:27-49

Clapham PJ (2000) The humpback whale: seasonal feeding and breeding in a baleen whale. In: Mann J, Conner RC, Tyack PL, Whitehead H (eds) Cetacean societies. University of Chicago Press, Chicago, p 173-196

Clapham PJ, Mayo CA (1990) Reproduction of humpback whales (Megaptera novaeangliae) observed in the Gulf of Maine. Rep Int Whal Comm Spec Issue 12:171-175

* Clapham PJ, Palsbøll PJ, Mattila DK, Vasquez O (1992) Composition and dynamics of humpback whale competitive groups in the West Indies. Behaviour 122:182-194

Connor RC, Read AJ, Wrangham R (2000) Male reproductive strategies and social bonds. In: Mann J, Conner RC, Tyack PL, Whitehead H (eds) Cetacean societies. University of Chicago Press, Chicago, p 247-269

Craig AS, Herman LM, Gabrielle CM, Pack AA (2003) 
Migratory timing of humpback whales (Megaptera novaeangliae) in the central North Pacific varies with age, sex and reproductive status. Behaviour 140:981-1001

Dalla Rosa L, Secchi ER, Maia YG, Zerbini AN, HeideJørgensen MP (2008) Movements of satellite-monitored humpback whales on their feeding ground along the Antarctic Peninsula. Polar Biol 31:771-781

Dulau-Drouot V, Cerchio S, Jouannet V, Ersts P, Fayan J, Boucaud V, Rosenbaum H (2011) Preliminary comparison of humpback whale photographic identifications indicates connectivity between Reunion (BS C4) and Madagascar (BS C3). Paper SC/63/SH28 presented to the IWC Scientific Committee, Cambridge

Dulau-Drouot V, Boucaud V, Fayan J, Mouysset L (2012) Occurrence and residency patterns of humpback whales off Réunion Island during 2004-2008. J Cetacean Res Manag 12:255-263

Ersts PJ, Rosenbaum HC (2003) Habitat preference reflects social organization of humpback whales (Megaptera novaeangliae) on a wintering ground. J Zool (Lond) 260: 337-345

Ersts PJ, Kiszka J, Vély M, Rosenbaum HC (2011a) Density, group composition, and encounter rates of humpback whales (Megaptera novaeangliae) in the eastern Comoros Archipelago (C2). J Cetacean Res Manag Spec Iss 3: 175-182

Ersts PJ, Pomilla C, Kiszka J, Cerchio S and others (2011b) Observations of individual humpback whales utilizing multiple migratory destinations in the southwestern Indian Ocean. Afr J Mar Sci 33:333-338

Findlay KP (2001) A review of humpback whale catches by modern whaling operations in the Southern Hemisphere. Mem Queensl Mus 47:411-420

Findlay KP, Best PB, Meyer M (2011a) Migrations of humpback whales past Cape Vidal, South Africa, and an estimate of the population increase rate (1988-2002). Afr J Mar Sci 33:375-392

Findlay KP, Meyer M, Elwen S, Kotez D and others (2011b) Distribution and abundance of humpback whales, Megaptera novaeangliae, off the coast of Mozambique 2003. J Cetacean Res Manag Spec Iss 3:163-174

Fossette S, Heide-Jørgensen MP, Jensen MV, Kiszka J, Bérubé M, Bertrand N, Vély M (2014) Humpback whale (Megaptera novaeangliae) post breeding dispersal and southward migration in the western Indian Ocean. J Exp Mar Biol Ecol 450:6-14

Gales NM, Double C, Robinson S, Jenner C and others (2009) Satellite tracking of southbound East Australian humpback whales (Megaptera novaeangliae): challenging the feast or famine model for migrating whales. Paper SC/61/SH17 presented to the IWC Scientific Committee, Cambridge

Garrigue C, Zerbini AN, Geyer Y, Heide-Jørgensen MP, Clapham PJ (2010) Movements of satellite-monitored humpback whales from New Caledonia. J Mammal 91: 109-115

Hauser N, Zerbini AN, Geyer Y, Heide-Jørgensen MP, Clapham PJ (2010) Movements of satellite-monitored humpback whales from the Cook Islands. Mar Mamm Sci 26:679-685

Heide-Jørgensen MP, Kleivane L, Oien N, Laidre KL, Jensen MV (2001) A new technique for deploying satellite transmitters on baleen whales: tracking a blue whale (Balaenoptera musculus) in the North Atlantic. Mar Mamm Sci 17:949-954
Heide-Jørgensen MP, Laidre KL, Wiig O, Jensen MV and others (2003) From Greenland to Canada in ten days: track of bowhead whales, Balaena mysticetus, across Baffin Bay. Arctic 56:21-31

Herman LM, Tavolga W (1980) The communication systems of cetaceans. In: Herman LM (ed) Cetacean behavior: mechanisms and functions. Wiley Interscience, New York, NY, p 149-209

Höglund J, Alatalo RV (1995) Leks. Princeton University Press, Princeton, NJ

Horton TW, Holdaway RN, Zerbini AN, Hauser N, Garrigue C, Andriolo A, Clapham PJ (2011) Straight as an arrow: humpback whales swim constant course tracks during long-distance migration. Biol Lett 7:674-679

International Whaling Commission (1998) Report of the scientific committee. Rep Int Whaling Comm 48:53-118

International Whaling Commission (2007) Annex H: report of the sub-committee on other Southern Hemisphere Whale Stocks. J Cetacean Res Manag 9:188-209

Jackson JA, Ross-Gillespie A, Butterworth D, Findlay K and others (2015) Southern hemisphere humpback whale comprehensive assessment-a synthesis and summary: 2005-2015. Paper SC/66a/SH03 presented to the IWC Scientific Committee, May 2015, Cambridge

Jayasankar P, Anoop B, Rajagopalan M (2008) PCR-based sex determination of cetaceans and dugong from the Indian seas. Curr Sci 94:1513-1516

Jonsen ID, Myers RA, Flemming JM (2003) Meta-analysis of animal movement using space-state models. Ecology 84 : 3055-3063

Jonsen ID, Flemming JM, Myers RA (2005) Robust statespace modeling of animal movement data. Ecology 86: 2874-2880

Jonsen ID, Myers RA, James MC (2007) Identifying leatherback turtle foraging behaviour from satellite telemetry using a switching state-space model. Mar Ecol Prog Ser 337:255-264

Kennedy AS, Zerbini AN, Vásquez OV, Gandilhon N, Clapham PJ, Adam O (2014) Local and migratory movements of humpback whales (Megaptera novaeangliae) satellite-tracked in the North Atlantic Ocean. Can J Zool 92:9-18

Kershaw F, Carvalho I, Loo J, Pomilla C and others (2016) Multiple processes drive genetic structure of humpback whale (Megaptera novaeangliae) populations across spatial scales. Mol Ecol (in press), doi:10.1111/Mec.13943

Kiszka J, Vely M, Breysse O (2010) Preliminary account of cetacean diversity and humpback whale (Megaptera novaeangliae) group characteristics around the Union of the Comoros (Mozambique Channel). Mammalia 74: $51-56$

Lagerquist BA, Mate BR, Ortega Ortiz JG, Winsor M, Urbán Ramirez J (2008) Migratory movements and surfacing rates of humpback whales (Megaptera novaeangliae) satellite tagged at Socorro Island, Mexico. Mar Mamm Sci 24:815-830

Mate BR, Gisiner R, Mobley J (1998) Local and migratory movements of Hawaiian humpback whales tracked by satellite telemetry. Can J Zool 76:863-868

Minton G, Cerchio S, Collins T and others (2010) A note on the comparison of humpback whale tail fluke catalogues from the Sultanate of Oman with Madagascar and the East African mainland. J Cetacean Res Manag 11:65-68

Minton G, Collins T, Findlay K, Ersts P, Rosenbaum H, Berg- 
gren P, Baldwin R (2011) Seasonal distribution, abundance, habitat use and population identity of humpback whales in Oman. J Cetacean Res Manag Spec Iss 3: 185-198

Mobley JM Jr, Herman LM (1985) Transience of social affiliations among humpback whales (Megaptera novaeangliae) in the Hawaiian wintering grounds. Can J Zool 63: 762-772

Notarbartolo di Sciara G, Smeenk C, Rudolph P, Addink M and others (2014) Summary review of cetaceans of the Red Sea. Paper presented to the IWC Scientific Committee, May 2014, Cambridge

Payne RS, McVay S (1971) Songs of humpback whales. Science 173:585-597

Pinheiro JC, Bates DM (2000) Mixed-effects models in S and S-Plus. Springer-Verlag, New York, NY

* Pinheiro J, Bates D, DebRoy S, Sarkar D, R Development Core Team (2015) Nlme: linear and nonlinear mixed effects models. R package version 3.1-120, http:// CRAN.R-project.org/package $=$ nlme

Pomilla C, Rosenbaum HC (2006) Estimates of relatedness in groups of humpback whales (Megaptera novaeangliae) on two wintering grounds of the Southern Hemisphere. Mol Ecol 15:2541-2555

Pomilla C, Amaral AR, Collins T, Minton G and others (2014) The world's most isolated and distinct whale population? Humpback whales of the Arabian Sea. PLOS ONE 9: e114162

R Core Team (2015) R: a language and environment for statistical computing. R Foundation for Statistical Computing, Vienna

Rasmussen K, Palacios D, Calmbokidis J, Saborio MT and others (2007) Southern Hemisphere humpback whales wintering off Central America: insights from water temperature into the longest mammalian migration. Biol Lett 3:302-305

Rosenbaum HC, Walsh PD, Razafindrakoto Y, Vely M, DeSalle R (1997) First description of a humpback whale breeding ground in Baie d'Antongil, Madagascar. Conserv Biol 11:312-314

Editorial responsibility: Peter Corkeron, Woods Hole, Massachusetts, USA
Rosenbaum HC, Pomilla C, Mendez M, Leslie MS and others (2009) Population structure of humpback whales from their breeding grounds in the South Atlantic and Indian Oceans. PLOS ONE 4:e7318

Rosenbaum HC, Maxwell SM, Kershaw F, Mate B (2014) Long-range movement of humpback whales and their overlap with anthropogenic activity in the South Atlantic Ocean. Conserv Biol 28:604-615

Kusk DC, Bertagne RG Associates (2014) Petroleum geology and geophysics of the Mozambique Channel. www. petromarex.com/projects/moz/

Trudelle L, Cerchio S, Zerbini AN, Geyer Y and others (2016) Influence of environmental parameters on movements and habitat utilization of humpback whales (Megaptera novaeangliae) in the Madagascar breeding ground. R Soc Open Sci 2016:160616, https://doi.org/ 10.1098/rsos.160616

* Tyack P, Whitehead H (1983) Male competition in large groups of wintering humpback whales. Behaviour 83: $132-154$

*Tyrrell M, Jielai X, Kuitai S, Chandler P (2015) A new oil play in east Africa. GEO ExPro 11:46-50

Vely M, Bastid JJ, Perri M, Mayer FX, Rabearisoa N, Ibrahima SM, Bertrand N (2009) Humpback whale monitoring at Isle Sainte-Marie, Madagascar, and in the Comoros Archipelago (Western Indian Ocean), from 1999 to 2008, based on whale-watching. In: Indian Ocean Cetacean Symposium, 18-20 July 2009, Ile Sainte Marie

Zerbini AN, Andriolo A, Heide-Jørgensen MP, Pizzorno JL and others (2006) Satellite-monitored movements of humpback whales (Megaptera novaeangliae) in the Southwest Atlantic Ocean. Mar Ecol Prog Ser 313:295-304

Zerbini AN, Andriolo A, Heide-Jørgensen MP, Moreira S and others (2011) Migration and summer destinations of humpback whales (Megaptera novaeangliae) in the western South Atlantic Ocean. J Cetacean Res Manag Spec Iss 3:113-118

Zuur AF, Ieno EN, Walker NJ, Saveliev AA, Smith GM (2009) Mixed effect models and extensions in ecology with R. Springer, New York, NY

Submitted: April 11, 2016; Accepted: October 25, 2016

Proofs received from author(s): December 21, 2016 